\section{CROSSHEAD SPEED EFFECTS ON FERRO CASTING DUCTILE (FCD) TENSILE STRENGTH AND FAULT MORPHOLOGY}

\author{
ANDOKO ANDOKO \\ Mechanical Engineering Department, State University of \\ Malang, Indonesia \\ DOI: 10.17973/MMSJ.2019_10_2019036 \\ e-mail: andoko.ft@um.ac.id
}

Nodular cast iron or Ferro casting ductile (FCD) is the developmental result of grey cast iron. Nodular cast iron has mechanical properties similar to carbon steel, which are better than the mechanical properties of grey cast iron. The $1.5 \mathrm{~mm} / \mathrm{s}$ crosshead speed created a tensile strength of $549.8 \mathrm{~N} / \mathrm{mm}^{2}$. It gradually declined to $401.4 \mathrm{~N} / \mathrm{mm}^{2}$ at $4.5 \mathrm{~mm} / \mathrm{s}$ and $302.6 \mathrm{~N} / \mathrm{mm}^{2}$ at $9 \mathrm{~mm} / \mathrm{s}$. Differentiation in strain rates at the speed variations caused the decline in tensile strength, creating energy lost due to the plastic deformation that resulted in the quick break in the specimen. The increase in strain rates influenced the yield strength results. These occurrences meant that the slower pullout generated a more static material. Thus, there was no declination in the tensile strength. Observed from the fault morphology results, a variant with $1.5 \mathrm{~mm} / \mathrm{s}$ speed had ductile fractures, $4.5 \mathrm{~mm} / \mathrm{s}$ speed variant had a combination of ductile-brittle fractures and $9 \mathrm{~mm} / \mathrm{s}$ speed variant had brittle fractures.

KEYWORDS

Nodular Cast Iron, Tensile Strength, and Fault Morphology

\section{INTRODUCTION}

Metal casting is a process of making cast objects through designing, moulding, melting, pouring, removal, and cleaning $[1,2]$. According to the American Society of Materials, the USA produced $75 \%$ of 23 million tons casting by using sand casting in 2015 [3] because of its cheap materials [4] and ability to cast complex geometries [5]. To resolve the metal casting disadvantages, British Cast Iron Research Association, in 1948, combined cerium alloy, nickel alloy and other alloys, creating created nodular cast iron [6]. Ever since, tests have been conducted to generate a better cast iron quality, one of which is by adding magnesium into the cast iron [7].

Based on metallography test result, additional magnesium and cerium in cast iron generated nodular graphite [8]. Nodular graphite has similar physical and mechanical properties to carbon steel, from its tensile strength, good elastic modulus, and ductility $[9,10]$. This founding was patented in 1949, and the USA declared the year as the year of nodular cast iron [11]. Graphite in nodular cast iron fills $10-15 \%$ of the total material volume and evenly distributed in the matrix structure, similar to carbon steel [12]. Cast iron has several microstructure varieties, e.g., soft ferrite structure, ductile ferrite structure, and hard ferrite structure. To change them into ferrite and bainite requires additional alloys and heat treatment [13].

Tensile test on steel plate material with acceleration (displacement control) and loads (load control) variations [14]. As well as the rate of corrosion also varies $[15,16]$. The result showed that speed rate variations generated a decrease in tensile strength. A high-speed rate tensile strength on an autobody steel sheet with the intermediate tensile test [17]. The result indicated that steel strain sensitivity rate in low speed was higher than that at high speed. Stress-strain curve generally declined due to the increase in strain rate and strength that resulted in higher tensile strength. In practice, only a handful of the material (especially nodular iron) researchers take note of crosshead speed effects on the tensile test result. To date, the tensile test is conducted manually without setting the speed variations. Thus, it makes for an interesting research topic. The tensile test followed the speed setting of ASTM A370-03a standard that limits the acceleration on specimen's tensile test and elongation to avoid any effect on the results. This research aimed to determine and analyze the maximum material strain through tensile test, strain, stress, and tensile test curve with 1.5 $\mathrm{mm} / \mathrm{s}, 4.5 \mathrm{~mm} / \mathrm{s}$, and $9 \mathrm{~mm} / \mathrm{s}$ cross speed rate variations. One way to determine the quality of mechanical properties in a material is by conducting a tensile strength test. The tensile test also determines material's properties, e.g., yield strength, elongation, surface reduction, elastic modulus, strain, and stress [18]. Speed variations are chosen to facilitate the depiction of material characteristics from ductile to brittle.

\section{RESEARCH METHOD}

This research used FCD 40 material that corresponded to ASTM A395 standard with the compositions of $3-4 \% \mathrm{C}$ as the main composition, up to $2.9 \% \mathrm{Si}$, and $0.05 \% \mathrm{P}$. Specimen was made through metal casting. Casting process consisting of processing and moulding melted Ferro until it became liquid in an induction furnace then poured into the cast [11]. Pouring temperature ranged from $1250^{\circ}$ to $1450^{\circ} \mathrm{C}$ to avoid direct contact with the casting wall. Direct contact with the casting wall resulted in a quick cooling below the liquidus temperature. Additional magnesium and cerium inoculation were required to create a nodular iron cast. Inoculation aimed to trigger graphite growth and evenly distributed the graphite inside the liquid metal [19].

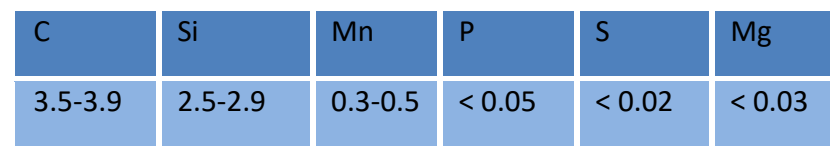

Table 1. FCD 40 Chemical Compositions.

Note. Retrieved from ASTM A395.

Tensile test with speed variations used ASTM E8 standard [20]. This research used a machine from Hung Ta HT-9502 (serial number: 1146) with 50,000 Kgf capacity. The tensile test was conducted with velocity varieties of $1.5 \mathrm{~mm} / \mathrm{s}, 4.5 \mathrm{~mm} / \mathrm{s}$, and 9 $\mathrm{mm} / \mathrm{s}$. ASTM A370-03a displacement control limited the speed to 0.5 fy to avoid any effect on the result. When that point was reached, the speed then limited up to $100 \mathrm{~mm} / \mathrm{s}$ and the acceleration reduction should have been no less than $1 / 10$ $\mathrm{mm} / \mathrm{s}$. The allowed tensile strength started from $0.625 \mathrm{~mm} / \mathrm{s}$ 
and up to $100 \mathrm{~mm} / \mathrm{s}$ with the load control between 1429-1408 $\mathrm{kgf} / \mathrm{s}$ [21].

After tested with a tensile test using crosshead speed of 1.5 $\mathrm{mm} / \mathrm{s}, 4.5 \mathrm{~mm} / \mathrm{s}$, and $9 \mathrm{~mm} / \mathrm{s}$; the specimen was cut up to $5 \mathrm{~cm}$ long and observed using scanning electron microscopy FEI brand Inspect-S50 type.

\section{RESULTS}

\subsection{The Description of Tensile Test Result}

The tensile test was administered to observe the cross speed effects on tensile strength, yield strength, elongation and time fracture with speed variations of $1.5 \mathrm{~mm} / \mathrm{s}, 4.5 \mathrm{~mm} / \mathrm{s}$ and 9 $\mathrm{mm} / \mathrm{s}$. Table 2 and Figure 1 show the tensile test results as below.

The figure 1 shows that there is a decrease in the tensile strength after speed variations treatment. It also indicates that cross speed variation affects tensile strength and shock deformation that in turn affecting the material structure [17]. The tensile strength also declined with changes of control in the displacement.

Figure 1 shows that yield strengths undergo a decrease. The speed of $1.5 \mathrm{~mm} / \mathrm{s}$ has the highest yield strength that is 236 $\mathrm{N} / \mathrm{mm}^{2}$, whereas $4.5 \mathrm{~mm} / \mathrm{s}$ has a yield strength of $179 \mathrm{~N} / \mathrm{mm}^{2}$, and $9 \mathrm{~mm} / \mathrm{s}$ speed has the lowest yield strength of $151 \mathrm{~N} / \mathrm{mm}^{2}$. This declination is proportional to the decrease of tensile strength after cross speed variations treatment. The reason behind this is due to the changes in shocking phase on the material. The tensile strength increases gradually along with the increase of load rate, affecting the value of tensile strength. However, strain-stress curves will decrease [22].

There was more than $70 \%$ declination on $9 \mathrm{~mm} / \mathrm{s}$ speed tensile strength. The increasing tensile strength during the increase of strain rate resulted in the low strength below the displacement and hardness average that was lower than the strain rate. The decreasing pouring temperature also influenced this phenomenon during the casting process. Tensile properties on intermediate strain rate requires cylinder speed accuracy verification with the initial input of $0.1 \mathrm{~mm} / \mathrm{s}$ (in accordance to UTM statical standard). The strain rate at $1.5 \mathrm{~mm} / \mathrm{s}$ speed is considered to be quasistatic [23]. The three specimens surface area of 28.27 were tested with three strain rate variations. Load reflect rate phenomenon occurred initially and declined along with the increasing strain rate. Specimen vibration also affected load accuracy by tightening the crossing jig that influenced strain rate into a constant value in yield point area. The increasing strain rate influenced the increasing yield strength. This occurrence indicated that the slow pullout made the material experience a static condition that in turn affecting the tensile strength. More strain discrepancies found in time variations meant that there were more fractures in the material due to the plastic diffusion. A quicker piston force resulted in a strainer distance between the atoms that it only required a little force to break it and higher strength to pull [24].

The highest elongation value that is $11.2 \%$ is achieved at 4.5 $\mathrm{mm} / \mathrm{s}$ speed, as seen in Figure 1. The lowest speed variation, 1.5 $\mathrm{mm} / \mathrm{s}$, has a lower elongation that is $11 \%$. And the lowest elongation of all, $10.2 \%$, was achieved at $9 \mathrm{~mm} / \mathrm{s}$ speed. The above statistics show that the materials with 4.5 and $1.5 \mathrm{~mm} / \mathrm{s}$ cross speed variations treatment have ductile fractures while FCD with $9 \mathrm{~mm} / \mathrm{s}$ has brittle property. They are consistent with the fact that fast speed acceleration influences more brittleness in the material [24]. Generally, elongation value is the opposite of tensile strength, but this research has different results. The longest elongation rate in this research is consistent with the increased tensile strength, at $4.5 \mathrm{~mm} / \mathrm{s}$. An inconstant strain caused this result during the process and the influence of vibration $[17,24]$.

Figure 1 shows that the longest time to fracture was achieved at $1.5 \mathrm{~mm} / \mathrm{s}$ with the time of $200 \mathrm{secs}$. Speed variation of $4.5 \mathrm{~mm} / \mathrm{s}$ results in a time fracture of 90 secs. And speed variation of 9 $\mathrm{mm} / \mathrm{s}$ results in a time fracture of 68 secs. In conclusion, crosshead speed has some effects on tensile strength. The faster the pullout means decline in tensile strength and it makes it be consistent with the yield strength. Specimen with faster cyclic load generated a brittle specimen [24].

Tensile strength, yield strength, elongation and time fracture on FCD samples test results were noted and concluded after conducting a tensile test with cross speed variations. Sample with $1.5 \mathrm{~mm} / \mathrm{s}$ speed has the tensile strength of $549.8 \mathrm{~N} / \mathrm{mm}^{2}$, $4.5 \mathrm{~mm} / \mathrm{s}$ speed has the strength of $401.4 \mathrm{~N} / \mathrm{mm}^{2}$ and the highest speed of $9 \mathrm{~mm} / \mathrm{s}$ has the lowest strength that is 302.6 $\mathrm{N} / \mathrm{mm}^{2}$, which is in contrast with the acceleration.

Crosshead speed also affects the yield strength values. Figure 1 shows that $1.5 \mathrm{~mm} / \mathrm{s}$ speed has $236 \mathrm{~N} / \mathrm{mm}^{2}$ yield strength, 4.5 $\mathrm{mm} / \mathrm{s}$ speed has $176 \mathrm{~N} / \mathrm{mm}^{2}$ yield strength and $9 \mathrm{~mm} / \mathrm{s}$ has the yield strength of $151 \mathrm{~N} / \mathrm{m}^{2}$. The data verify that crosshead speed affects yield strength value through changes in the shock phase that takes place without an initial phase. However, crosshead speed has less impact on the samples' elongation.

\begin{tabular}{|c|c|c|c|c|c|c|}
$\begin{array}{c}\text { Crosshead } \\
\text { Speed } \\
\text { Variations }\end{array}$ & $\begin{array}{c}\text { Area } \\
\left(\mathrm{mm}^{2}\right)\end{array}$ & $\begin{array}{c}\text { Max Force } \\
(\mathrm{N})\end{array}$ & $\begin{array}{c}0,2 \% \text { Yield } \\
\text { Strength } \\
\left(\mathrm{N} / \mathrm{mm}^{2}\right)\end{array}$ & $\begin{array}{c}\text { Tensile } \\
\text { Strength } \\
\left(\mathrm{N} / \mathrm{mm}^{2}\right)\end{array}$ & Elongation (\%) & $\begin{array}{c}\text { Time } \\
(\mathrm{sec})\end{array}$ \\
\hline $1.5 \mathrm{~mm} / \mathrm{s}$ & 28.27 & 1554 & 23.67 & 549.8 & 11 & 200 \\
\hline $4.5 \mathrm{~mm} / \mathrm{s}$ & 28.27 & 1135.5 & 17.98 & 401.4 & 11.25 & 90.2 \\
\hline $9 \mathrm{~mm} / \mathrm{s}$ & 28.27 & 1146.5 & 15.145 & 302.6 & 10.7 & 68.7 \\
\hline
\end{tabular}

Table 2. Tensile Test with Crosshead Speed Variations Results 


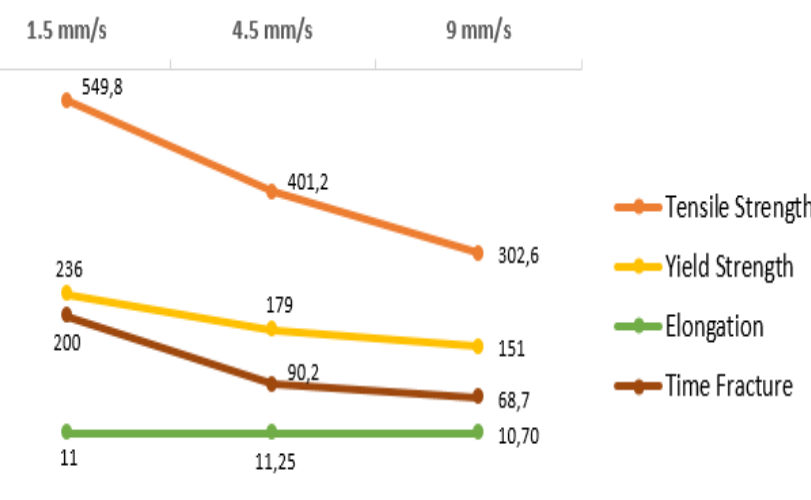

Figure 1. Crosshead Speed Correlation with Tensile Strength, Yield Strength, Elongation, and Time Fracture.

\subsection{The Description of Tensile Test Result}

Fault morphology test was used to observe the material properties. There are two categories for fractures: ductile and brittle fractures, depending on whether the material experiences plastic deformation or not before the failure [18]. Figure 2(a) shows a macro photo of the ductile fracture in the specimen with $1.5 \mathrm{~mm} / \mathrm{s}$ speed due to the dimples and relatively greyish colour on the surface. Fracture with greyish colour means that it is ductile [19]. Figure 2(b) shows some fibrous fractures that absorb light and greyish. Ductile fracture also has fibrous surface and tends to be rough, indicating a high absorbance of energy during the fault test that generates plastic deformation and results in good tensile strength [25]. The result of fracture from tensile test can be seen in Figure 2 . The fracture pattern can show the surface contour of the ductile and brittle characteristics of the metal with cross speed rate variations.

Dimple fracture that occurred because of a reduction of the surface during statical load can be observed on the surface contour. Split load in the fracture area takes place through the plastic loading process. Sharp split initially arises because of the fracture in the tensile load, creating a $45^{\circ}$ angle. A high crosshead speed generates shocking changes and results in a brittle plastic area, which differs from a slow crosshead speed where the crack rate is proportional to the speed. It can be concluded that the standard speed makes the crack rate in materials proportionate with its fracture standard. In this research, jagged and dimple fractures that were found in the fracture microstructure and the high elongation define the ductile fracture at $1.5 \mathrm{~mm} / \mathrm{s}$ speed [4].

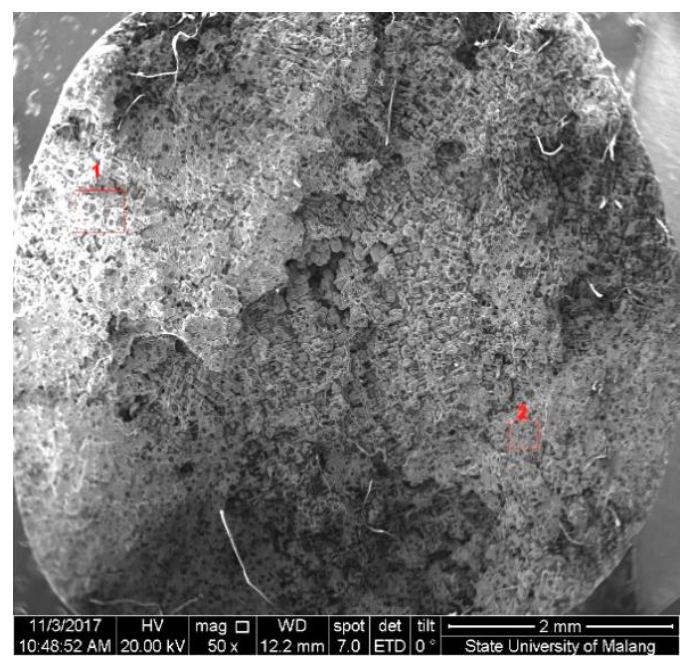

a.

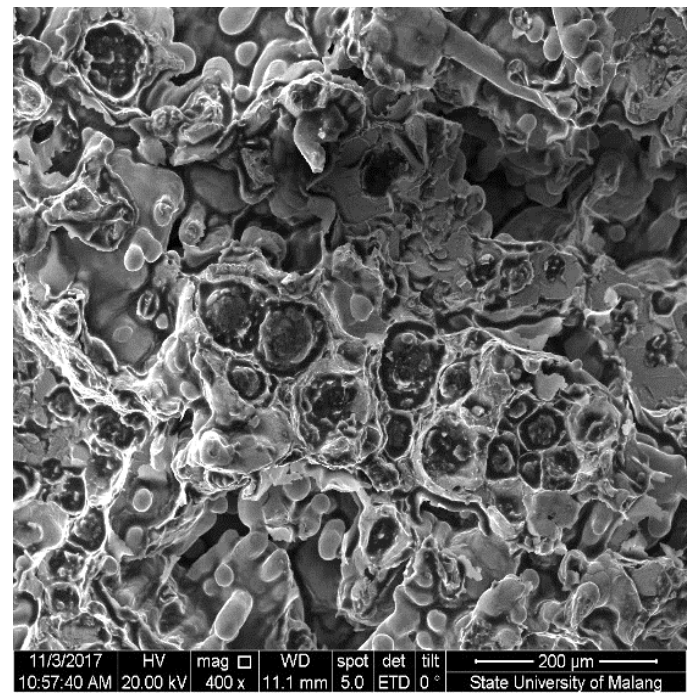

b.

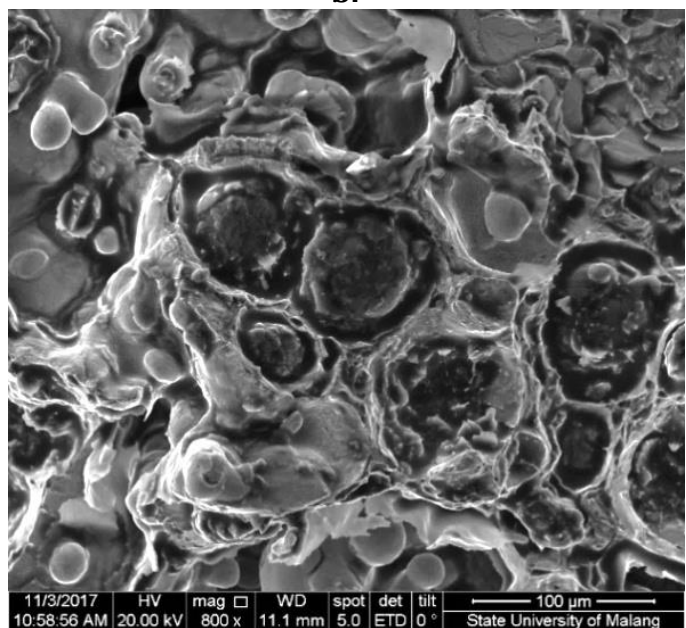

c. 


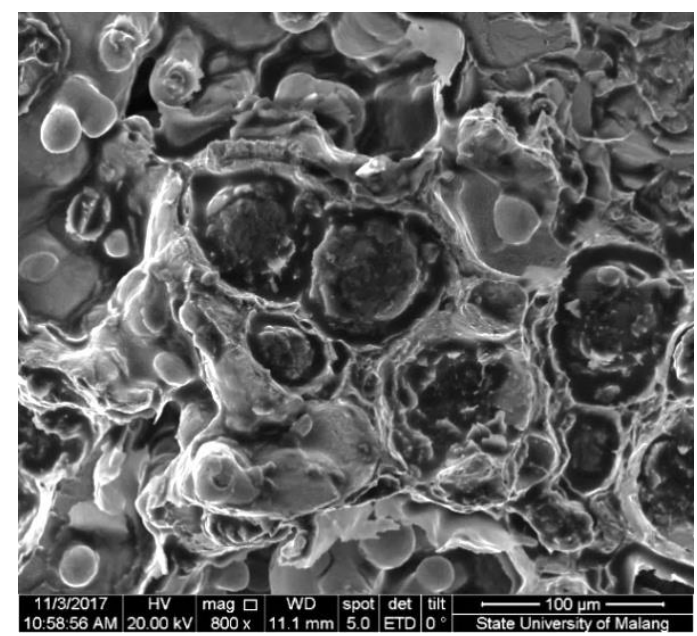

d.

Figure 2. Fracture Surface of Nodular Cast Iron after Tensile Strength Test with 9 mm/s Crosshead Speed (a) Macro Photo, (b) 400x Magnifications, (c) 800x Magnifications, (d) 2000x Magnifications.

Figure 3 shows the cleavage appearances that make it brittle. Brittle fracture dominates; and as seen in Figure 4(a) and (b), there are cleavages (intergranular fracture) in the intercellular area. Cleavage is a low energy transgranular fracture that mainly comes from the separation of low index atomic bonds [25]. Cleavage can be found inside the particles of crystallography area. Cleavage fracture changes its direction when crossing the intergranular fracture and graphite nodules, similar to a river pattern [26]. Cleavage fracture generally occurred in high microstructure strength (with low plasticity) and tended to take place in the inclusion around the eutectic cell boundary rather than in the distance between nodular interfaces [27]. Figure 3 shows that the stance between the nodule and the hollow at $4.5 \mathrm{~mm} / \mathrm{s}$ speed is relatively small and plentiful compared to that at $1.5 \mathrm{~mm} / \mathrm{s}$. The small distance shows that the material has a brittle property [6].

The brittle fracture occurred because of the plastic deformation and a quick particle separation that created cleavage [13]. The surface of brittle fracture is flat in shape, shiny bright-coloured, and has a high reflectivity. Fracture surface after a load control is identified through the final form. A short displacement of speed affects the fracture form and ductility. Sharp split initially arises because of the fracture in the tensile load, creating a $45^{\circ}$ angle. A high crosshead speed generates shocking changes and results in a brittle plastic area, which differs from a slow crosshead speed where the crack rate is proportional to the speed. It can be concluded that the standard speed makes the crack rate in materials proportionate with its fracture standard. The sample fracture form, similar to a river pattern and plentiful in its microstructure, shows that this is a brittle sample.

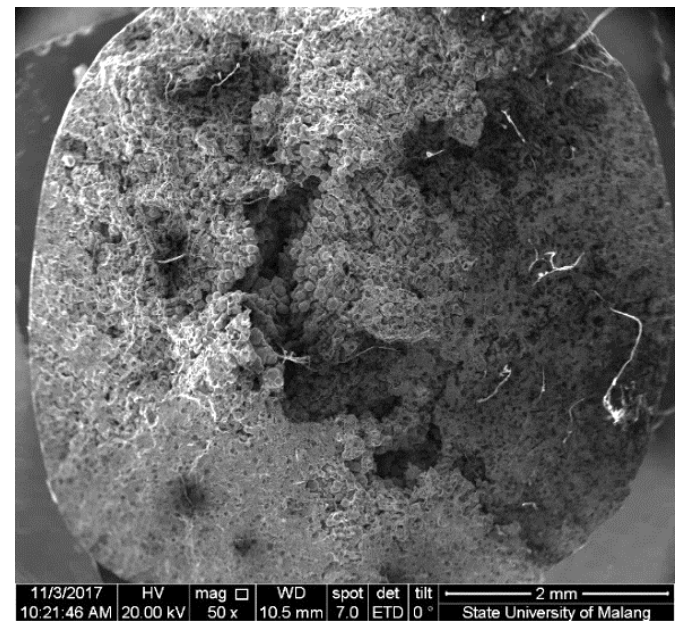

a.

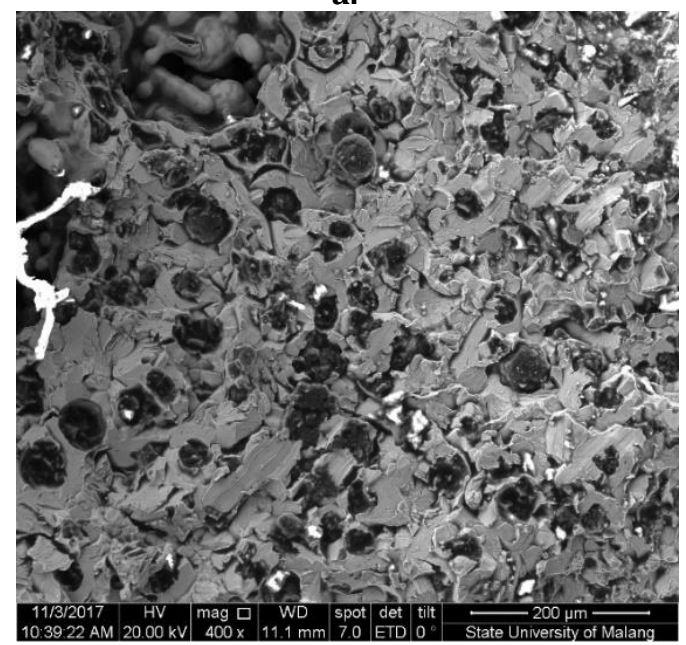

b.

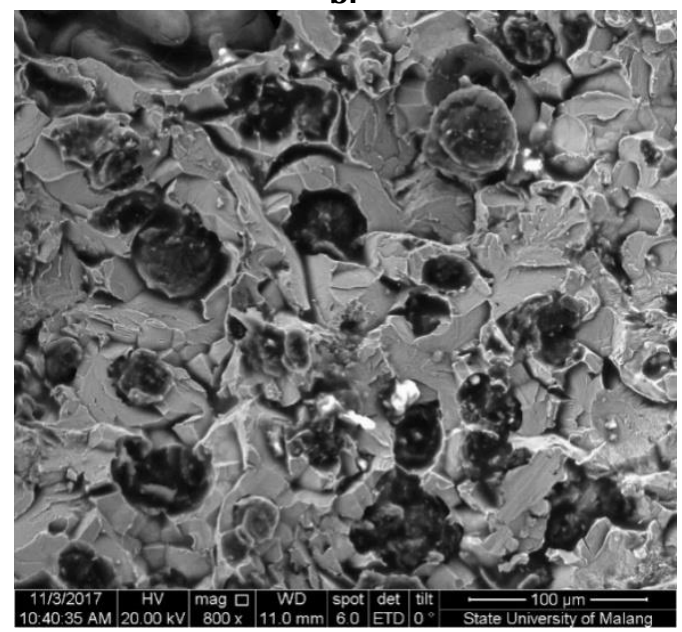

c. 


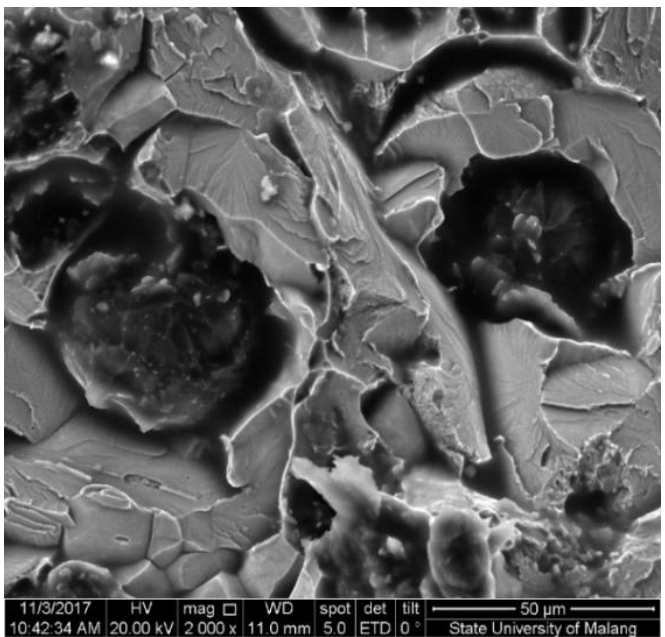

d.

Figure 3. Fracture Surface after Tensile Strength Test with $4.5 \mathrm{~mm} / \mathrm{s}$ Crosshead Speed (a) Macro Photo, (b) 400x Magnifications, (c) 800x Magnifications, (d) 2000x Magnifications.

Figure 4 shows a combination of brittle and dimple fractures on the specimen with $9 \mathrm{~mm} / \mathrm{s}$ speed treatment as seen in the plentiful dimples and uneven greyish fault. Brittle fracture dominates Figure 4(a) and (b) as observed in the cleavage (intergranular fracture) found in the intercellular area. Cleavage is a low energy transgranular fracture that mainly comes from the separation of low index atomic bonds [25]. Cleavage can be found inside the particles of crystallography area. Cleavage fracture changes its direction when crossing the intergranular fracture and graphite nodules, similar to a river pattern [28]. Cleavage fracture generally occurred in high microstructure strength (with low plasticity) and tended to take place in the inclusion around the eutectic cell boundary rather than in the distance between nodular interfaces [27].

Figure 4 shows that the distance between the nodule and the hollow at $9 \mathrm{~mm} / \mathrm{s}$ speed is relatively small and plentiful compared to that at $1.5 \mathrm{~mm} / \mathrm{s}$. The small distance indicates that the material has a brittle property [6]. The brittle fracture occurred because of the plastic deformation and a quick particle separation that created cleavage [13]. The surface of brittle fracture is flat in shape, shiny bright-coloured, and has a high reflectivity [29].

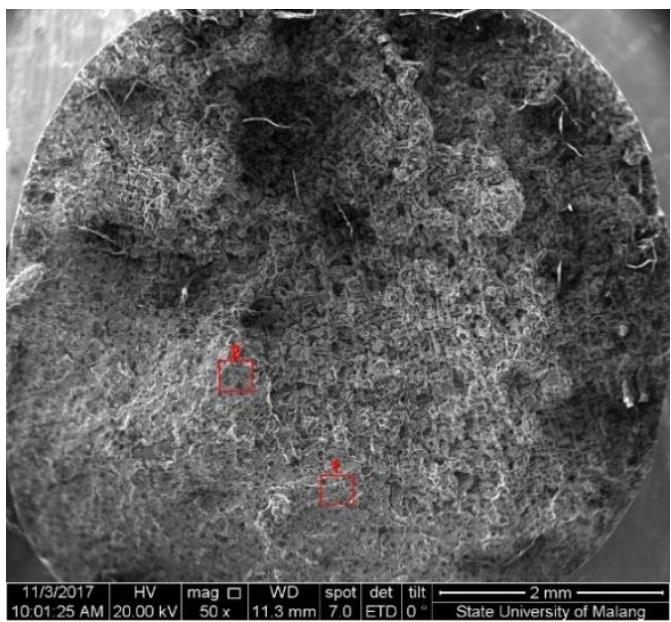

a.

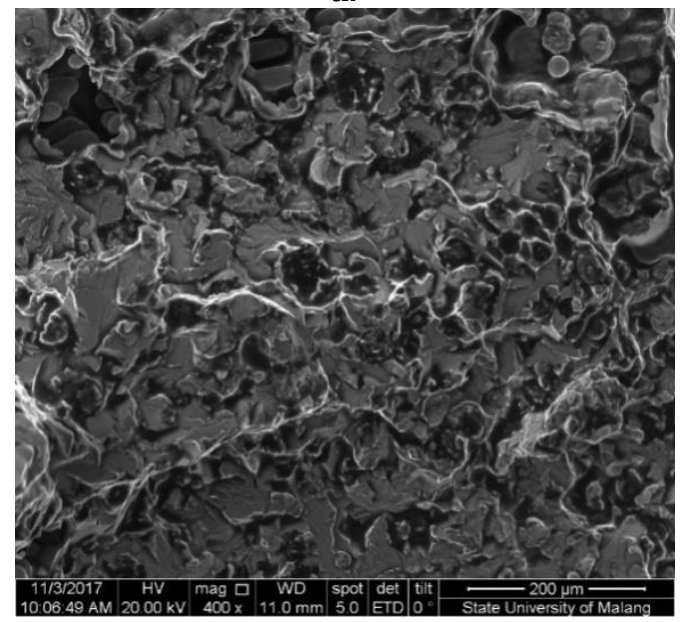

b.

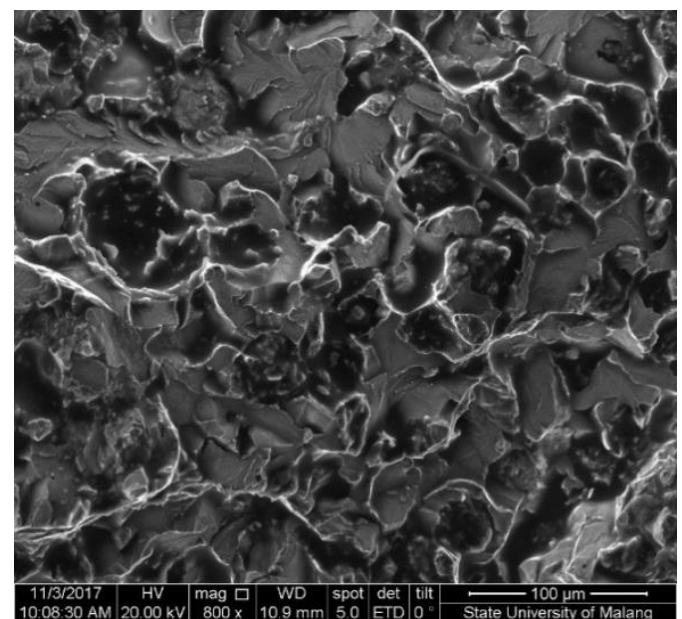

c.

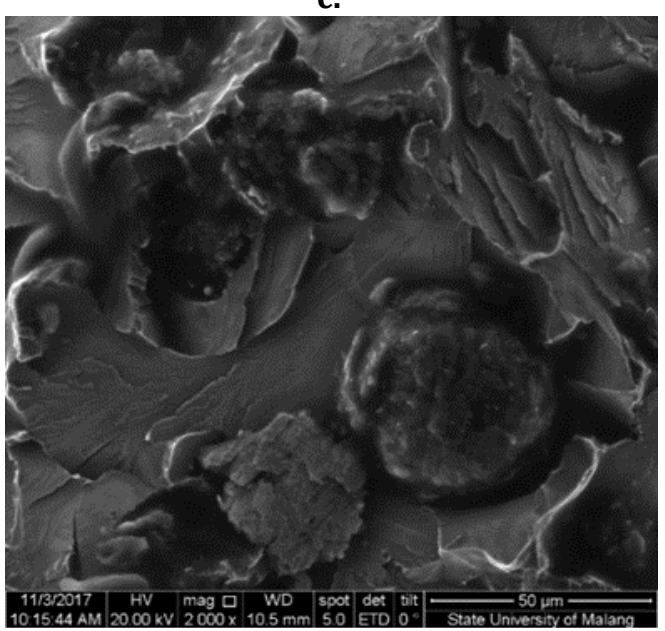

d.

Figure 4. Fracture Surface after Tensile Strength Test with $9 \mathrm{~mm} / \mathrm{s}$ Crosshead Speed (a) Macro Photo, (b) 400x Magnifications, (c) 800x Magnifications, (d) 2000x Magnifications.

A high crosshead speed generates shocking changes and results in a brittle plastic area, which differs from a slow crosshead speed where the crack rate is proportional to the speed. It can be concluded that the standard speed makes the crack rate in materials proportionate with its fracture standard. The sample 
fracture form, that is similar to river pattern and plentiful in its microstructure, shows that this is a brittle sample.

\section{CONCLUSIONS}

In conclusion, FCD tensile strength after tested with crosshead speed variation experienced a decrease along with the acceleration speed. The speed of $1.5 \mathrm{~mm} / \mathrm{s}$ has the highest tensile strength of $549.8 \mathrm{~N} / \mathrm{mm} 2$, while $4.5 \mathrm{~mm} / \mathrm{s}$ speed has the strength of $401.4 \mathrm{~N} / \mathrm{m}^{2}$. The lowest strength was found at $9 \mathrm{~mm} / \mathrm{s}$ speed with $302.6 \mathrm{~N} / \mathrm{mm}^{2}$. Different strain rates at the speed variations caused the decline in tensile strength, causing energy lost due to the plastic deformation that caused the quick break in the specimen.

Changes also occurred in the fault morphologies with the crosshead speed variations. Speed variation of $1.5 \mathrm{~mm} / \mathrm{s}$ has a relative ductile fault due to the plentiful dimples in the surface. Speed variation of $4.5 \mathrm{~mm} / \mathrm{s}$ has a combination of ductile-brittle fractures with brittle domination. Speed variation of $9 \mathrm{~mm} / \mathrm{s}$ has brittle fault due to the plentiful cleavages that dominate the surface.

\section{ACKNOWLEDGMENTS}

The author thanks LPPM, the State University of Malang for supporting this research under PNBP Program 2019.

\section{REFERENCES}

[1] [Campbel 2007] Campbell, J. Filling and Feeding System Concepts. ASM Handbook Volume 15 "Castings" Ed. S. Viswanathan. Birmingham: University of Birmingham ,2007.

[2] [Setyarini 2018] Setyarini, P.H., Gapsari, F., and Purnomo., Fabrication of Aluminum Using Casting Method Made for Anodizing Process on Biomaterial Applications, International Conference on Mechanical Engineering Research and Application, 23-25 October 2018, Malang, Indonesia., IOP Conference Series: Materials Science and Engineering, 494, ISBN 9781510884861.

[3] [Ductile Iron society 2015] Ductile Iron society, ductile Iron Data for Design Engineers. http://www.ductile.org/didata/ pdf/didata2.pdf, 9, dt. 12/04/2015.

[4] [Souza 2014] Souza, T.N.F., Nogueira, R.A.P.S., Franco, F.J.S., Aguilar, M.T.P. and Cetlin, P.R. Mechanical and Microstructural Characterization of Nodular Cast Iron (NCI) with Niobium Addition. Journal of Engineering, October 2014, Vol.17, No.5. ISSN 1516-1439

[5] [Fierro 2001] Fierro, V.E., Sikora, J.A., Agüera, F.R., Alvarez Villar, H.N., Ansaldi, A.F. and Ratto, P.J.J. Fractomechanical Properties of As-Cast and Austempered SG Cast Iron Between $-40{ }^{\circ} \mathrm{C}$ and $+20{ }^{\circ} \mathrm{C}$. Journal of Engineering, December 2001, Vol.5, No.2. ISSN 1516-1439

[6] [Fatahallla 1996] Fatahalla. N. and Bahi, S. Metallurgical Parameters, Mechanical Properties and Machinability of Ductile Cast Iron. Journal of Engineering, November 1996, Vol.31, No.21, pp 5765-5772
[7] [Callister 2007] Callister, W.D. Materials Science and Engineering: an Introduction, 7th ed. United States of America: 2007. ISBN-13: 978-0-471-73696-7

[8] [Caldera 2007] Caldera, M., Chapetti, M., Massone, J. M., and Sikora, J. A. Influence of Nodule Count on Fatigue Properties of Ferritic Thin Wall Ductile Iron. Material Science and Technology, 2007, Vol.23, No.8., pp 10001004.

[9] [Andoko 2014] Andoko, A., Soenoko, R., Purnowidodo, A. and Surya Irawan, $Y$.The Effects of Two-Steps Austempering Heat Treatment on the Tensile Strength and Toughness of Nodular Cast Iron. ARPN Journal of Engineering and Applied Science, 2014.

[10] [Gapsari 2019] Gapsari, F., Wijaya, H., Andoko, and Suprapto, A. The Performance of Bee Wax Propolis Inhibitor on the Ductile Cas Iron (DCl) In Saline And Acidic Environment. International Review on Modelling and Simulations, 2019 Vol. 12, N.3.

[11] [AFS 2015] AFS 115th Metal casting Congress, April 5-8, 2011- Schaumburg, IL USA

[12] [Stokes 2007] Stokes, B. Effects of Graphite Nodules on Crack Growth Behaviour of Austempered Ductile Iron. Materials Science and Engineering, February 2007, Vol.445-446, pp 374-385

[13] [Bish 2009] Bish, A. Effect of Heat Treatment Procedure and Microstructure and Mechanical properties on Nodular Iron. Thesis Master Technology. Rourkela: Department of Metallurgical and Material Engineering, 2009.

[14] [Gapsari 2019] Gapsari, F., Madurani, K.A., Simanjuntak, F.M., Andoko, A. Wijaya, H. and Kurniawan, F. Corrosion Inhibition of Honeycomb Waste Extracts for 304 Stainless Steel in Sulfuric Acid Solution, Materials, vol. 12, no. 13, 2019.

[15] [Gapsari 2016] Gapsari, F., Soenoko, R., Suprapto, A. and Suprapto, W. Green Inhibitor For Api $5 \mathrm{~L}$ X65 Steel In HCl $0.5 A R P N$ Journal of Engineering and Applied Science, Vol. 11, pp. 9524-9527, 2016.

[16] [Ganda 2018] Ganda, A.N.F., Andoko, Setyarini, P.H. and Gapsari, F. The Inhibitive Effect of Tannin in Psidium Guajava Leaves towards 304SS Corrosion in Concentrated $\mathrm{HCl}$. International Mechanical Engineering Conference, 6-7 August 2018, Malang, Indonesia, MATEC Web of Conferences, Vol. 204, 05018, 2018

[17] [Huh 2004] Huh, H., Lim, J. H., Kim, S. B., Han, S. S. and Park, S. H. Formability of the Steel Sheet at the Intermediate Strain Rate. Key Engineering Materials, 2004, pp 274-276.

[18] [Malaque 2013] Maleque, M.A. and Salit, M.S. Mechanical Failure of Materials. Materials Selection and Design, December 2013, pp 17-38

[19] [ASM 1990] ASM International, 1990. Asm Handbook: Properties and Selection: Nonferrous Alloys and SpecialPurpose Materials (Asm Handbook) VOL. 2, 10th edition. ed. ASM International, Materials Park, Ohio.

[20] [ASTM 2004] ASTM International, 2004. Standard Test Methods for Tension Testing of Metallic Materials [Metric].

[21] [ASTM 2017] ASTM, 2017. ASTM Book of Standards Volume 01.04: Iron and Steel Products: Steel - Structural, Reinforcing, Pressure Vessel, Railway [WWW Document]. URL (accessed 11.23.17). 
[22] [Steinberg 2017] Steinberg, D. J., Cochran, S. G. and Guinan, M. W. A constitutive Model for Metals Applicable

at High-Strain Rate. J. Applied Physics, 1980, Vol.51, No.3., pp 1498-1504

[23] [Instron 2002] Instron Corporation (2002). Operating Instructions of Instron FastTrack 8800 and Materials Test Control Systems.

[24] [Huh 2002] Huh, H., Kang, W. J. and Han, S. S. A Tension split Hopkinson Bar for Investigating the Dynamic Behavior of Sheet Metals. Experimental Mechanics. Experimental Mechanics, 2002, pp 8-17.

[25] [Udomphol 2013] Udomphol, 2013. Tensile Testing. Mech. Metall. Lab.

[26] [[Boneti 2017] Boneti, L.L.T., Hupalo, M.F., Vurobi Junior, S. and Rosário, A.M. Influence of Casting Heterogeneities on Microstructure and Mechanical Properties of
Austempered Ductile Iron. Revista Materia, 2017. ISSN 1517-7076

[27] [Pannerselvam 2017] Panneerselvam, S., Putatunda, S.K., Gundlach, R. and Boileau, J. Influence of Intercritical Austempering on the Microstructure and Mechanical Properties of Austempered Ductile Cast Iron (ADI). Mater Science and Engineering, May 2017, Vol.694, pp 72-80

[28] [Basso 2013] Basso, A.D., Martínez, R.A. and Sikora, J.A. Analysis of Mechanical Properties and Its Associated Fracture Surfaces in Dual-Phase Austempered Ductile Iron, Dual-Phase ADI, Matrix Microstrukture, Fracture Surface. Fatigue Fract. Eng. Mater.Struct, July 2013

[29] [Basso 2007] Basso, A.D., Martínez, R.A. and Sikora, J.A. Influence of Austenitising and Austempering Temperatures on Microstructure and Properties of Dual Phase ADI. Material Science and Technology, 2007

\section{CONTACT}

Dr Andoko

Mechanical Engineering Department,

State University of Malang, Semarang Street no. 5

Malang, Indonesia 65145

+628123352726

e-mail: andoko.ft@um.ac.id 